\title{
Diffusion Rates for Elevated Releases
}

Prepared by J. V. Ramsdell

Pacific Northwest Laboratory

Operated by

Battelle Memorial Institute

Prepared for

U.S. Nuclear Regulatory

Commission 


\section{NOTICE}

This report was prepared as an account of work sponsored by an agency of the United States Government. Neither the United States Government nor any agency thereof, or any of their employees, makes any warranty, expressed or implied, or assumes any legal liability of responsibility for any third party's use, or the results of such use, of any information, apparatus, product or process disclosed in this report, or represents that its use by such third party would not infringe privately owned rights.

\section{Availability of Reference Materials Cited in NRC Publications}

Most documents cited in NRC publications will be available from one of the following sources:

1. The NRC Public Document Room, 1717 H Street, N.W. Washington, DC 20555

2. The NRC/GPO Sales Program, U.S. Nuclear Regulatory Commission, Washington, DC 20555

3. The National Technical Information Service, Springfieid, VA 22161

Although the listing that follows represents the majority of documents cited in NRC publications, it is not intended to be exhaustive.

Referenced documents available for inspection and copying for a fee from the NRC Public Document Room include NRC correspondence and ir,ternal NRC memoranda; NRC Office of Inspection and Enforcement bulletins, circulars, information notices, inspection and investigation notices; Licensee Event Reports; vendor reports and correspondence; Commission papers; and applicant and licensee documents and correspondence.

The following documents in the NUREG series are available for purchase from the NAC/GPO Sales Program: formal NRC staff and contractor reports, NRC-sponsored conference proceedings, and NRC booklets and brochures. Also available are Regulatory Guides, NRC regulations in the Code of Federal Regulations, and Nuclear Regulatory Commission Issuances.

Documents available from the National Technical Information Service include NUREG series: reports and technical reports prepared by other federal agencies and reports prepared by the Atomic Energy Commission, forerunner agency to the Nuclear Regulatory Commission.

Documents available from public and special technical libraries include all open literature items, such as books, journal and periodical articles, and transactions. Federal Register notices, federal and state legislation, and congressional reports can usually be obtained from these libraries.

Documents such as theses, dissertations, foreign reports and translations, and non-NRC conference proceedings are available for purchase from the organization sponsoring the publication cited.

Single copies of NRC draft reports are available free upon written request to the Division of Tech. nical Information and Document Control, U.S. Nuclear Regulatory Commission, Washington, DC 20555.

Copies of industry codes and standards used in a substantive manner in the NRC regulatory process are maintained at the NRC Library, 7920 Norfolk Avenue, Bethesda, Maryland, and are available there for reference use by the public. Codes and standards are usually copyrighted and may be purchased from the originating organization or, if they are American National Standards, from the American National Standards Institute, 1430 Broadway, New York, NY 10018. 
NUREG/CR-3368

PNL-4772

\section{Diffusion Rates for Elevated Releases}

Manuscript Completed: July 1983

Date Published: November 1983

Prepared by

J. V. Ramsdell

Pacific Northwest Laboratory

Richland, WA 99352

\section{Prepared for}

Division of Systems Integration

Office of Nuclear Reactor Regulation

U.S. Nuclear Regulatory Commission

Washington, D.C. 20555

NRC FIN B2514 



\section{ABSTRACT}

A search of the literature related to diffusion from elevated sources has determined that an adequate data base exists for use in developing parameterizations for estinating diffusion rates for material released from free standing stacks at nuclear power plants. A review of published data analyses indicates that a new parameterization of horizontal diffusion rates specifically for elevated releases is not likely to significantly change the magnitudes of horizontal diffusion coefficients on the averaye. However, the uncertainties associated with horizontal diffusion coefficient estimates under any given set of atmospheric conditions could be reduced by a new parameterization. Similarly, a new parameterization of vertical diffusion rates would be unlikely to significantly alter the maynitudes of diffusion coefficients for unstable atmospheric conditions. However, for neutral and stable atmospheric conditions, a new parameterization of vertical diffusion rates might increase vertical diffusion coefficients significantly. The increase would move ground-ievel timeintegrated concentration miaxima closer to the plant and would increase the inaxima. 


\section{ACKNOWLEUGEMENTS}

The assistance of Dr. R. K. Hadlock at PNL and the staff of the Meteorology and Effluent Treatment Branch of the NRC Division of Systens Integration, specifically Mr. James Fairobent, NRC Technical Monitor, and Mr. Earl Markee, during the course of the work was greatly appreciated. 



\section{CONTENTS}

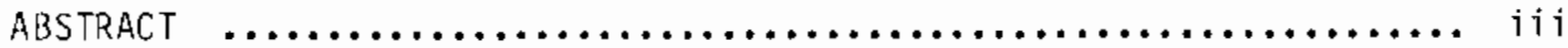

ACKNOWLEDGEMENTS................................. v

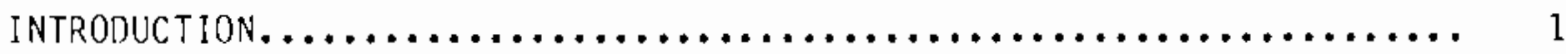

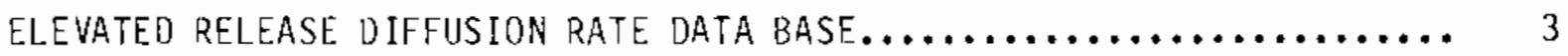

CONVENTIONAL ELFVATED RELEASE DIFFUSION EXPERIMENTS.......... 3

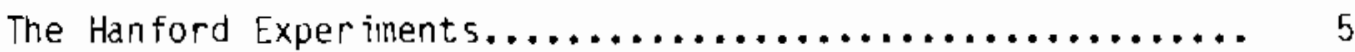

The Julich Experiments..........................

The Karisruhe Experinents....................... 6

IN SITU ELEVATED RELEASE DIFFUSION EXPERIMENTS............ 7

SYNOPSIS OF THE CONVENTIONAL ELEVATED RELEASE DATA..............

HORIZONTAL DIFFUSION RATES........................

VERTICAL DIFFUSION RATES........................ 1 ?

CONCLIISIONS AND RECOMMENDATIONS ..................... 16

CONCLUSIONS.................................. 16

RECOMMENDATIONS............................ 17

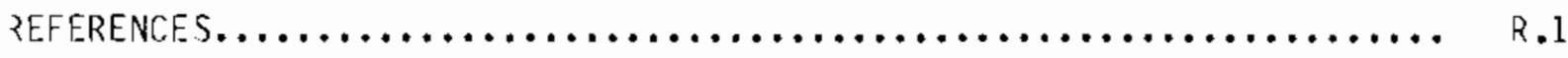




\section{TABLES}

1. Conventional Elevated Releases Diffusion Studies.............. 4

2. Distribution of the Elevated Releases at Hanford by Release Height and Time-of-Day............................... 5

3. LIDAR P1 une Studies.................................. 7

4. Other In Situ Flevated Release Experiments.................. 8

\section{FIGURES}

1. Comparison of Horizontal Diffusion Coefficient

Curves for El evated Releases...............................

2. Comparison of Vertical Diffusion Coefficient

Curves for Elevated Releases............................... 



\section{INTRODUCTION}

The continuous-source Gaussian plume diffusion model is a practical choice for use in evaluating the consequences of potential and actual releases from nuclear power plants because of its simplicity and flexibility. The basic model is given by

$$
x(x, y, z)=\frac{Q^{\prime}}{2 \pi U \sigma_{y} \sigma} \exp \left\{-\frac{1}{2}\left[\left(\frac{y}{\sigma_{y}}\right)^{2}+\left(\frac{z-h_{e}}{\sigma_{z}}\right)^{2}\right]\right\}
$$

where $x(x, y, z)$ is the concentration at a point $(x, y, z), Q^{\prime}$ is the rate at which material is released, $U$ is the mean wind speed, $h_{e}$ is the effective release height, and $\sigma_{y}$ and $\sigma_{z}$ are the diffusion coefficients, which are usually given as functions of atmospheric stability and distance from the source. The center line of the plume lies along the $x$-axis. From this starting point models have been developed for a variety of special applications including estimation of annual average concentrations and estimation of concentrations during trapping (fumigation) conditions.

The wind speed can be measured, and the effective release height can be estimated from the meteorological conditions at the release point, the release characteristics and terrain. The remaining parameters required by these models are the diffusion coefficients. Unlike the wind speed and effective release height, which are essentially point values, the diffusion coefficients are integral values that represent the atmospheric conditions within the plune between the source and the receptor. Specifically, the diffusion coefficients are related to atmospheric turbulence. A general formulation for diffusion coefficients can be written as:

$$
\sigma(x)=\sigma_{0}+\int_{0}^{x} i(x) s(x) d x
$$

where $\sigma_{0}$ is related to the initial source dimension, $i(x)$ is a turbulence intensity and $s(x)$ is a function that describes the effectiveness of the turbulence in diffusion. At large distances from the source, $\sigma_{0}$ may be neglected if the initial source dimensions are sinall. Under this condition, the source may be considered to be a point source.

Historically, most diffusion coefficients have been determined from data obtained in experiments using ground-level sources and receptors. These diffusion coefficients have been applied to evaluation of concentraions from both ground-level and elevated releases, even though the turbulence characteristics of the atmosphere are known to vary as a function of the height above ground.

Diffusion data are available for experiments using elevated release points. The objectives of this study are: 
1) to identify existing data sets that may be used to evaluate diffusion rates for elevated releases,

2) to review existing analyses of these data to determine if there appear to be significant differences in diffusion rates for ground-level and elevated releases.

3) to evaluate the adequacy of the elevated release data for developing new diffusion coefficient parameterizations for use with elevated releases, and

4) to recommend a course of action for the NRC staff with respect to the development and incorporation of elevated release diffusion coefficients in guidance to applicants and licensees.

The next section describes the data base that is available for use in evaluating the diffusion rates for elevated release. Sources of data include experiments in which the releases were made for the specific purpose of obtaining diffusion data and experiments that made use of existing releases. A synopsis of the results of these experiments is presented after the available data sets are described. The final section of the report discusses the adequacy of the data for developing new diffusion paraneterizations and contains recommendations related to the development of new parameterizations. 


\section{ELEVATED RELEASE DIFFUSION RATE DATA BASE}

Elevated release diffusion experiments have been conducted at many locations using a wide variety of tracers and techniques for data collection. As a result, the experiments could be classified in many ways. However, as the number of classes increases, the number of tests in each class decreases and differentiation between the effects of natural random variations and true differences in mean diffusion rates becomes difficult.

For the present purposes, the elevated diffusion data base is divided into just two classes. The first class contains those experiments that correspond most closely to the diffusion tests used to develop diffusion rates for groundlevel releases. Typically, these experiments involve point sources, carefully selected tracers, sampling locations and test conditions, and detailed supporting meteorological measurements. The experiments in this class will be referred to as the conventional elevated release diffusion experiments. The second class contains experiments conducted under conditions that are less ideal. Typically, experiments in this class make use of sources of opportunity, which may be too large to be considered point sources for close-in measurements. The experiments in this class will be referred to as the in situ experiments.

Comparing characteristics of the experiments in the two classes further, the conventional experiments are likely to have more ground-level concentration measurements than the in situ experiments, and are more likely to have been conducted in relatively simple topographic settings. A relatively large number of the in situ experiments have been conducted in valleys, near coasts and in other complex topographic settings. Perhaps as a result of complex terrain settings, the in situ experiments have tended to make more extensive use of techniques, such as aircraft sampling and LIDAR, to sampie the elevated plume directly.

The renainder of this section describes the available elevated release cata base. The conventional elevated release diffusion experiments are described first and in somewhat more detail than the in situ experiments.

\section{CONVENTIONAL ELEVATED RELEASE DIFFUSION EXPER IMENTS}

Elevated release diffusion experiments at 14 locations have tentatively been $p l a c e d$ in the conventional experiment category. These experiments are listed in Table 1 by location. The experiments at Porton, Brookhaven, Idaho Falls, Harwe 11 and 16 early experinents at Hanford are described by Islitzer and Slade (1968). Stewart's (1968a and 1968b) experinents in Canada were similar to the Porton Experiments. The experiments at Karlsruhe and Julich followed the general design of the Idaho Falls and Hanford experiments, but were conducted over terrain with more relief and larger surface roughness elements. Of the more recent experiments, the Danish experiments of Gryning and lyck (1980) are most similar to the early conventional experiments. 
TAPE 1. Conventional Elevated Releases Diffusion Studies

\begin{tabular}{|c|c|c|c|c|c|c|}
\hline Location & Number & $\begin{array}{c}\text { teights } \\
(m) \\
\end{array}$ & $\begin{array}{l}\text { Duration } \\
\text { (min) } \\
\end{array}$ & $\begin{array}{l}\text { Distances } \\
(\mathrm{km}) \\
\end{array}$ & Stability & References \\
\hline itan ford, WA & 167 & $7-111$ & $30-60$ & $0.1-17.8$ & all & $\begin{array}{l}\text { Barad and Shorr 1954; } \\
\text { Hilst 1957; Hi lst and } \\
\text { Sirpson 1958; Elderkin, } \\
\text { Powell and Nickold 1974; } \\
\text { Nickola 1977; Doran, Horst } \\
\text { and Nickola 1978; Nickola } \\
1979\end{array}$ \\
\hline Julich, Gemany & 44 & 50,100 & 60 & to 11.0 & N & Voyt and Geiss 1974 \\
\hline Karlsruhe, Gemany & 33 & 60,100 & $20-120$ & $0.1-50.0$ & N & $\begin{array}{l}\text { Tharas et al. 1976; Tharas } \\
\text { and iester } 1976\end{array}$ \\
\hline Brookhaven, NY & & 108 & $30-90$ & & all 1 & $\begin{array}{l}\text { Sirith 1956; Singer and } \\
\text { Gini th 1966 }\end{array}$ \\
\hline Idaho Falls, ID & 16 & 46 & 30 & $0.1-3.2$ & U & Islitzer 1961 \\
\hline Porton, ISK & 19 & 150 & 30 & $0.03-0.15$ & $S-I J$ & Hay and Pasquill 1957 \\
\hline Canada & 7 & $18-92$ & $4-42$ & & U-S & Stewart 1968a and 1968b \\
\hline Riso, Demlark & 5 & 60 & 60 & 5.0 & N & Gryning and Lyck 1980 \\
\hline Copenhagen, Dermark & 10 & 115 & 60 & $2.0-6.0$ & $\mathrm{~N}-\mathrm{U}$ & Gryning and Lyck 1981 \\
\hline Hanell, IJK & & 68 & 60 & $0.15-10.0$ & all & $\begin{array}{l}\text { Stewart, cale and Crooks } \\
1958\end{array}$ \\
\hline
\end{tabular}

Experiments completed or planned for which data are not yet available Ibuntain home, ID 18 releases from 30 to $70 \mathrm{~m}$ elevation, ERA funded st udy Idaho Falls, ID NRC funded study for model validation 1981 Lake itichigan NRC funded study for model val idation 1982 Four Comers to be conducted by NOAA in 1983.

Four sets of experiments are listed at the botton of Table 1. The data from these experiments are not readily available at this time, but should becone available in the near future.

The Hanford, Julich and Karlsruhe data sets are described in the following paragraphs. The remainder of the large data sets, Brookhaven and Idaho Falls, are adequately described by Islitzer and Slade (1968). 
The Hanford Experinents

The largest single set of elevated release diffusion experiments was conducted at Hanford, Washington from 1963 through 1973. These experiments involved the release of a variety of tracers including $Z n S$, flouroscein, rhodamine dye and krypton-85 from heights ranging between 7 and $111 \mathrm{~m}$ above ground. The releases were generally 30 minutes in duration. Concentration measurements were made at a height of $1.5 \mathrm{~m}$ at distances to $12.8 \mathrm{k}$ (n and at several levels on towers to a distance of $3.2 \mathrm{~km}$. The diffusion and supporting meteorological data for the experiments from 1967 through 1973 have been pub1 ished by Nickola (1977); the data for the earlier experiments are being prepared for publication in the near future.

During the Hanford experiments, an effort was made to collect diffusion data for the full range of atmospheric conditions. Table 2 shows the distribution of releases by release height and time-of-day. Time-of-day gives a general indication of atmospheric stability. Many of these releases were made in multiple release experiments in which simultaneous releases were made at two or more elevations.

TABLE 2. Distribution of the Elevated Releases at Hanford by Release Height and Time-of-Day.

\begin{tabular}{crrrr} 
Time & $7 m$ & $\frac{26 m}{17}$ & $\frac{56 m}{25}$ & $\frac{111 m}{9}$ \\
\hline $0000-0159$ & 11 & 8 & 8 & 3 \\
$0200-0359$ & 7 & 8 & & \\
$0400-0559$ & 1 & & 5 & 1 \\
$0600-0759$ & 1 & 4 & 15 & \\
$0800-0959$ & & 12 & 10 & \\
$1000-1159$ & & 5 & & \\
$1200-1359$ & & 1 & & \\
$1400-1559$ & & & & \\
$1600-1759$ & & & &
\end{tabular}

The supporting meteorological data available for the Hanford experiments include complete surface weather observations, wind and temperature profiles from the surface to $125 \mathrm{~m}$, and additional turbulence data in the lowest $20 \mathrm{~m}$ of the atmosphere. 
The Julich Experiments

The second iargest set of elevated diffusion experiments was conducted at the Jul ich Nuclear Research Center in the Federal Republic of Germany (Vogt and Geiss 1974). The Julich Nuclear Research Center is located in the northwestern portion of the country, near the border between the Federal Republic of Gerinany and Holland. The vicinity of the Center consists of woodlands with fol iaged trees and conifers and arable land and pastures. As a result, the surface roughness is significantly larger than that found at Hanford.

The tracer releases were inade at the 50 and $100 \mathrm{~m}$ levels of a meteorological tower using copper sulfate tagged with copper-64 dispensed in solution through atomizers. The resulting aerosol was less then 5 microns in size. Release durations were generally one hour. Ground-level samples were collected at 100 locations on a sampling grid that extended to a distance of about $11 \mathrm{~km}$ from the release point. Of the 44 releases, 28 were inade from the 50 m level of the tower, and the remaining 16 were made from $100 \mathrm{~m}$. Meteorological conditions for the releases tended to be neutral to slightly unstable although some experiments were conducted in moderately stable and moderately unstable conditions. The general atmospheric stability was estimated using the scheme proposed by Pasquill (1961). Meteorological data are available for deterinination of diffusion coefficients using other parameterizations.

The Karlsruhe Experiments

Thomas et a1. (1976) and Thomas and Nester (1976) describe 25 diffusion experiments conducted at the Karlsruhe Nuclear Research Center up to 1974. The experiments consisted of releases of tritiated water vapor and halogenated hydrocarbons from a $100 \mathrm{~m}$ stack. Ground-level concentration measurements were made at distances from approximately 0.1 to $5 \mathrm{~km}$ from the 5 tack. Thonas et al. (1976) indicate that an additional 8 exper finents with releases at 60 in have been conducted and that future experiments might include releases fron elevations up to $200 \mathrm{~m}$.

The terrain in the vicinity of the Karlsruhe Nuclear Research Center is generally flat, but the site is is covered with buildings and trees. As a result, the roughness length, $z_{0}$, reported for the Karlsruhe site is about $1.1 \mathrm{~m}$. This is significantly larger than values of 0.03 and $0.01 \mathrm{~m}$ reported for the Hanford and Idaho Falls sites, respectively.

The Karlsruhe experinents were conducted during the day. lost of the data were collected during neutral atmospheric conditions. However, one of the experiments was conducted in slightly stable conditions, and six were conducted in slightly to extremely unstable conditions based on Pasquill's (1961) stability classification scheme. Again, complete neteorological data are avialable for use in developing new parameterizations for elevated release diffusion rates. 


\section{IN SITU ELFVATED RELEASE DIFFUSION EXPERIMENTS}

The in situ elevated diffusion experiments can be subdivided in almost as many ways as there are experiments. One of the most useful subdivisions is the group of experiments that have used LIDAR to observe the characteristics of the elevated plumes. Seven of these experiments are listed in Table 3.

\section{TABLE 3. LIOAR Plume Studies}

\begin{tabular}{|c|c|c|c|}
\hline Location & $\begin{array}{l}\text { He ight } \\
(\mathrm{m})\end{array}$ & $\begin{array}{c}\text { Distances } \\
(\mathrm{km}) \\
\end{array}$ & Re ferences \\
\hline Keystone, PA & 245 & $2.0-21.0$ & $\begin{array}{l}\text { Johnson 1969; Johnson and Jthe } \\
1971\end{array}$ \\
\hline Ostiglia, Italy & 120 & 1.0 & $\begin{array}{l}\text { Bacci, Elisei and Longhetto } \\
1974\end{array}$ \\
\hline Sacramento, CA & & & Uthe and Johnson 1976 \\
\hline Alberta, Canada & & $0.2-2.0$ & Hoff and Froude 1979 \\
\hline St. Louis, $M 0$ & & to 130 & Ithe and Wilson 1979 \\
\hline Cumberland, TN & 305 & 35 & Uthe, Ludwig and Pooler 1980 \\
\hline Nanticoke, Canada & 200 & to 40 & Hof $f$ et al. 1982 \\
\hline
\end{tabular}

The two-dimensional, vertical cross-sections of plumes that can be obtained with LIDAR can be used to estimate both the horizontal and vertical diffusion coefficients. The LIDAR experinents are particularly valuable because LIDAR is a measurenent technique that is capable of giving reliable, quantitative information on vertical diffusion coefficients at distances of more than a few hundred meters from the source. Other techniques for measuring vertical concentration profiles are generally Timited in usefulness to the immediate vicinity of the source.

Useful data appear to have been collected in the studies listed above, but only limited analyses of the data have been published. As a result, estimates of vertical diffusion coefficients must be made indirectly from ground-level concentration measurements and diffusion models. The cost of reduction and analysis of LIDAR data may be the reason for the small amount of quantitative data in the open literature.

A large number of in situ elevated source diffusion experinents are described in the open literature. Table 4 lists a number of the studies by location. Most of the plumes in these studies are from stacks with flow rates that are much larger than the flows from free-standing stacks at nuclear power plants. As a result, the datd from these studies need to be corrected for 
IABLE 4. Other In Situ Elevated Release Experiments

\begin{tabular}{|c|c|c|c|}
\hline Location & $\begin{array}{l}\text { Ye ight } \\
\text { (m) }\end{array}$ & $\begin{array}{l}\text { Bistances } \\
\quad(\mathrm{km}) \\
\end{array}$ & References \\
\hline Brookhaven, NY & 108 & to 300 & $\begin{array}{l}\text { Peterson 1968; Brown, Cohen and } \\
\text { Simith } 1972\end{array}$ \\
\hline Canada & 160 & & Whal ey 1974 \\
\hline $\begin{array}{l}\text { Huntington } \\
\text { Canyon, IJT }\end{array}$ & 183 & 10 & Start, Dickson and Wendell 1975 \\
\hline $\begin{array}{l}\text { Trail, British } \\
\text { Columbia }\end{array}$ & $37-122$ & $2-12$ & Whaley and Lee 1977 \\
\hline $\begin{array}{l}\text { Athabasca River } \\
\text { Valley, Alberta }\end{array}$ & $76-106$ & $2-25$ & Whaley and Lee 1978 \\
\hline Widows Creek, AL & $83-305$ & 3.2 & Hanna 1980 \\
\hline $\begin{array}{l}\text { Pincher Creek, } \\
\text { Alberta }\end{array}$ & & $0.5-20$ & Whaley, Lee and Gainer 1980 \\
\hline Tilbury, UK & 100 & & ioore 1974 \\
\hline Various & & $4-200$ & Gifford 1980 \\
\hline
\end{tabular}




\section{SYNDPSIS OF THE CONVENTIONAL ELEVATED RELEASE DATA}

This section summarizes the data available for estimating horizontal and vertical diffusion rates for elevated releases. Estimates of the elevated diffusion rates are also compared with diffusion rates for ground-level releases under similar atmospheric conditions.

\section{HORIZONTAL DIFFUSION RATES}

Horizontal diffusion coefficient parameterizations are generally a power law function of distance, i.e.

$$
\sigma_{y}(x)=a x^{b}
$$

where $x$ is the downwind distance and $a$ and $b$ may be functions of stability. Equation (3) follows from (2) when the intensity of turbulence is assumed to be independent of $x$ and $s(x)$ is assumed to have the form

$$
s(x)=c\left(\frac{x}{x_{0}}\right)^{\alpha}
$$

where $c$ is a constant with a value of about one, $x_{0}$ is a reference distance that can be a unit distance such as $1 \mathrm{~m}$, and the exponent $\alpha$ has a value of about -0.1. This parameterization has been used for both ground-level and elevated releases.

A common variation of (3) involves the use of measured wind direction fluctuations directly in the leading coefficient rather than estimating the coefficient indirectly through a stability classification scheme. In this case (3) becomes

$$
\sigma_{y}(x)=a^{\star} \sigma_{\theta} x^{b}
$$

where $a^{*}$ is a constant and $\sigma_{\theta}$ is the standard deviatior of the horizontal wind direction fluctuations. In this case, the exponent b is generally not a function of stability. This variation of (3) is justified because when $\sigma_{\theta}$ is expressed in radians, it is a good approximation of the lateral intensity of turbulence.

Elevated diffusion data for Hanford (Doran, Horst and Nickola 1978) and the National Reactor Testing Station (NRTS) at Idaho Falls (Islitzer 1961) have been summarized using (5). When a value of $\sigma_{\theta}$ is supplied, horizontal diffusion coefficients estinated with this relationship can be compared with those estimated from (3). 
Figure 1 compares the horizontal diffusion coefficient curves for Hanford, NRTS, Brookhaven, Julich and Karlsruhe elevated diffusion data with the corresponding curves used by the NRC to estinate diffusion coefficients for groundlevel releases. The NRC curves have been attributed to Eimutis and Konicek (1972) and are currently used in the MESODIF-II (Powe11, Fox and Wegley 1979). PAVAN (Bander 1982), and X0QD0Q (Sagendorf, Gol1 and Sandusky 1982) models. The values of $\sigma_{0}$ given for Stability $\mathrm{Cl}$ asses $B, D$, and $F$ in Regulatory Guide 1.23 (USNRC 1974) have been used to reduce the Hanford and NRTS relationships to the form of (3). Brookhaven diffusion classes $B_{1}, C$ and $D$ have been assumed to correspond to the NRC B, D and F stability classes, respectively.

During unstable conditions (Class B), the parameterizations are within a factor of two of one another for distances from 100 to $10^{5} \mathrm{~m}$.

The spread of the relationships for diffusion coefficients in neutral atmospheric conditions (Class D) is somewhat larger than for unstable conditions, but all curves still lie within a factor of two of the center of the band. The Karlsruhe tritiated water (HTO) curve departs significantiy from the others. The flat slope of the curve suggests that the plumes may have had relatively large initial plume dimensions that have not been taken into account properly. The diffusion coefficients measured by Gryning and Lyck (1980) for distances of $5 \times 10^{3}$ and $10^{4} \mathrm{~m}$ fall within the envelope of the curves that are shown.

With the exception of the Julich relationship, the horizontal diffusion coefficient curves for stable atmospheric conditions (Class F) are within a factor of two of an average value. The departure of the Julich relationship from the others for stable atmospheric conditions is marked. Thomas et al. (1976) and Thomas and Nester (1976) do not report any data for Karlsruhe for Class $F$ conditions, but their data for Class $E$ conditions tend to support the larger diffusion rates reported for the Julich data. It should be noted that the Julich and Karlsruhe data sets for stable atmospheric conditions are small.

No consistent pattern that can be attributed to release height is apparent in comparing these curves for the full range of atmospheric conditions. The NRC relationships are included to provide a reference for evaluating the other relationships. The Hanford, NRTS and Brookhaven curves, which are directiy related to atmospheric turbulence, give diffusion coefficient estimates that are near those obtained with the corresponding NRC relationships.

Surface roughness is not considered explicitly in estimating diffusion coefficients, but mechanical turbulence generated by wind passing over the surface roughness elements does affect the measured direction fluctuations. As a result, the schemes using wind direction fluctuations implicitly include consideration of surface roughness. Thus, the Brookhaven curves are relatively consistent with those from Hanford and NRTS even though there are significant differences in surface roughness between the sites.

The method of classifying atmospheric conditions used with the Juich and Karlsruhe data sets does not use turbulence data directly. Rather, it uses 

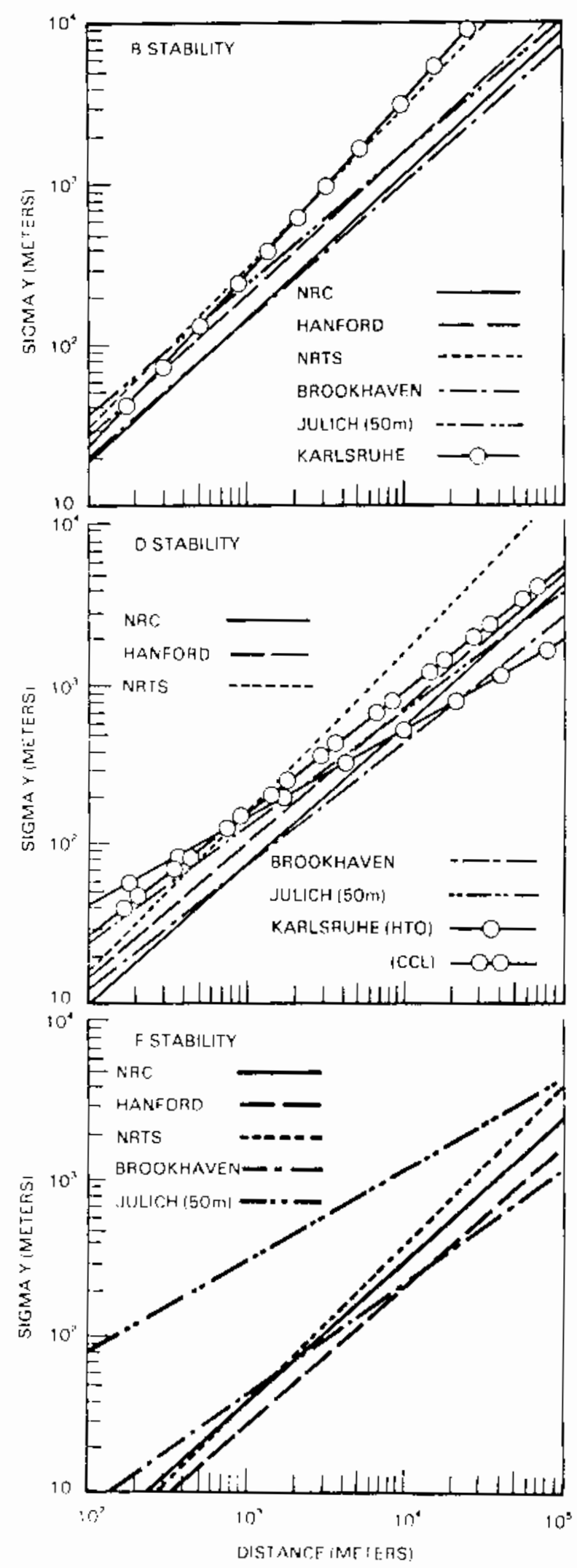

FIGURE 1. Comparison of Horizontal Diffusion Coefficient Curves for Elevated Releases 
synoptic meteorological information and a general classification scherne developed by Pasquill (1961) and Gifford (1961). Had the wind direction fluctuation data in the Julich and Karlsruhe data sets (Vogt and Geiss 1974, Thomas et a1. 1976 and Thomas and Nester 1976) been used to determine the diffusion conditions, the classes for the individual releases would have tended to be less stable. For example, the conditions for 22 release periods at Julich were classified as $D$ on the basis of the synoptic classification scheme. If classification had been on the basis of wind direction fluctuations at the release height and the class definitions in Regulatory Guide 1.23 (USNRC 1974), the stability class for three of these experiments would have been $D$; the remaining 19 experiments would have been classified as $\mathrm{C}$.

The analysis of the Hanford data by Doran, Horst and Nickola (1978) provides further support for the conclusion that the release height has little, if any, affect on horizontal diffusion. They found that the errors in estimating horizontal diffusion coefficients for releases from heights of 26 and 56 m were smaller on the average when low level wind direction fluctuations were used to make the estimates than when release height wind direction fluctuations were used.

\section{VERTICAL DIFFUSION RATES}

The estimation of vertical diffusion rates from experimental data is more complicated than the estimation of horizontal diffusion coefficients. In yeneral, the cost of obtaining a sufficient number of elevated samples within plumes to compute the vertical diffusion coefficients directly is prohibitive. As a result, the vertical diffusion coefficients are usually estimated indirectly using concentration measurements made near ground-level, computed horizontal diffusion coefficients, and diffusion models. Errors in the diffusion model, horizontal diffusion coefficients and concentration measurements lead to errors in the vertical diffusion coefficient estimates. Thus, more uncertainty exists in vertical diffusion rate estimates than is found in the estimates of horizontal diffusion rates. This uncertainty increases the difficulty in identifying any effects that release height might have on vertical diffusion rates.

The NRC uses a parameterization attributed to Eimutis and Konicek (1972) that is similar to (3) for estimating vertical diffusion coefficients in its diffusion models. The parameterization is

$$
\sigma_{2}(x)=a x^{b}+c
$$

where $a, b$ and $c$ are functions of stability. The values of a and b for (6) are different than those for (3). The additive constant, $c$, is needed to match segments of the model for three different distance ranges. The coefficients and exponents for the paraneterization were selected using ground-level release diffusion data. For releases in stable conditions and for short distances, the values are based, in part, on actual measurements of the vertical diffusion 
coefficients. In general, however, the values for the coefficients and exponents are based on vertical diffusion coefficients estimated indirectly using models. The vertical temperature gradient is the NRC's primary method for classifying atmospheric conditions for selecting the coefficients and exponents for the relationships.

Power law relationships identical to (3) that are functions of distance only have been used to summarize the Brookhaven, Julich and Karlsruhe vertical diffusion coefficient estimates. As in the case of the horizontal diffusion coefficients for Julich and Karlsruhe, the classification of atmospheric conditions for selecting the coefficients and exponents for the relationships is on the basis of synoptic variables. Visual characteristics of the horizontal wind direction trace are used to select the coefficient and exponent values for use in the Brookhaven relationship.

Vertical diffusion rates at NRTS during unstable atmospheric conditions were summarized by Islitzer (1961) as a function of the standard deviation of the elevation angle of the wind and distance. The relationship is the same as (5), except that $\sigma_{\phi}$ replaces $\sigma_{\theta}$.

Doran, Horst and Nickola (1978) do not provide a relationship to summarize the Hanford vertical diffusion coefficient estimates. However, they do provide measured vertical diffusion coefficients at 200 and $400 \mathrm{~m}$ for several experiments. The measured vertical diffusion coefficients compare favorably with predictions made using a theoretical model developed by chaudhry and Meroney (1973) for ground-level releases. Data that can be used to est imate vertical diffusion coefficients for many of the Hanford elevated releases are contained in the Hanford-67 data volume (Nickola 1977).

Figure 2 compares vertical diffusion coefficient curves for the elevated releases at Brookhaven, Julich and Karlsruhe and compares them with the corresponding curves currently used by the NRC. Vertical diffusion coefficient estimates for Hanford and from the Riso experiments of Gryning and Lyck (1980) are shown with the neutral and unstable curves.

With the exception of the Karlsruhe relationship, the curves for unstable conditions ( $C$ ass $B$ ) provide vertical diffusion coefficient estimates that cover a range of less than a factor of two. The Julich estimates are larger than the NRC estimates based on ground-level data, but the Brookhaven curve estimates vertical diffusion coefficients that are about the same as those estimated by the NRC curve.

For neutral atmospheric conditions (Ciass D), there is a definite separation in the estimates. The Brookhaven, Julich and Karlsruhe curves estimate vertical diffusion coefficients that range from about a factor of 1.5 higher than the NRC estimates to almost an order of magnitude higher. The Julich estimates are largest, and the Brookhaven estimates are closest to the NRC estimates. Masured vertical diffusion coefficients at 200 and $400 \mathrm{~m}$ for 26 and $56 \mathrm{~m}$ releases at Hanford tend to fall between estimates made using the Brookhavefi, and NRC curves. Estimates of vertical diffusion coefficients at about $5 \times 10^{3} \mathrm{~m}$ made by Gryning and Lyck (1980) range from a low that corresponds 

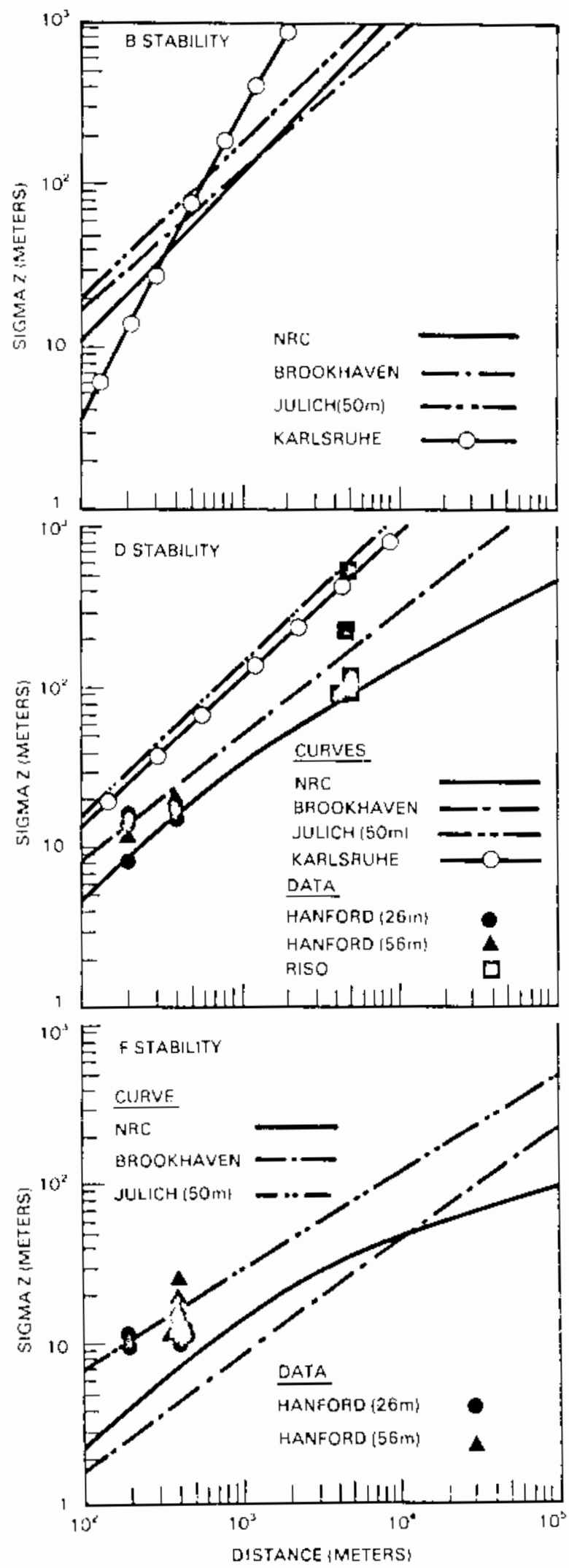

FIGURE 2. Comparison of Vertical Diffusion Coefficient Curves for El evated Releases 
with estimates made with the NRC curves to a high that corresponds with estimates made using the Julich and Karlsruhe curves.

For stable atmospheric conditions ( $\mathrm{Cl}$ asS $\mathrm{F}$ ), the Brookhaven and NRC curves give similar vertical diffusion coefficient estimates. These estimates are significantly smaller than those derived from the Julich curves and measured coefficients at 200 and $400 \mathrm{~m}$ at Hanford.

Comparing the curves and data over the full range of atmospheric conditions, the potential differences between diffusion coefficients for elevated releases and those for ground-level releases appear to be least for unstable conditions and increase with increasing atmospheric stability. This trend is in the proper direction to be an effect of release height, but the comparison is not conclusive. Other factors that could contribute to the differences include: variations in the methods of determining and classifying atmospheric conditions, differences in topography, and differences in the models used to estimate the vertical diffusion coefficients from the available data.

By comparing crosswind-integrated concentrations for simultaneous releases at different heights, Nickola (1979) provides evidence that the effects of release height on diffusion are more than can be accounted for by differences in the wind speed with increasing elevation. Nickola (1979) also shows that peak ground-level concentrations downwind of elevated releases occur closer to the source than would be expected using vertical diffusion coefficients developed from ground-level releases. This difference can be partially explained if vertical diffusion for elevated releases occurs at a faster rate than for ground-level releases.

The conventional elevated release data base is sufficient that a consistent analysis of the avaiable data might result in a clearer understanding of the effects of release height on vertical diffusion. The data most likely to yield usable results are those collected in experiments with simultaneous releases from two or more elevations. In order to obtain conclusive results from analysis of data from experiments run at different locations at different times, it will be necessary to resolve differences between the experiments related to surface conditions and characterization of the atmosphere. 


\section{CONCLUSIONS AND RECOMMENDATIUNS}

Evaluation of the data base identified in a literature search and consideration of the uses of diffusion coefficients in the evaluation of routine and accidental releases of radioactive effluents from nuclear power plants leads to the following conclusions and recominendations:

\section{CONCLUSIONS}

The data base available for use in parameterizing diffusion rates for elevated releases from nuclear power plant stacks is probably larger than the data base that was used in the initial development of the parameterizations currently used to est imate diffusion rates for ground-level releases. The data base includes measured ground-level concentrations and horizontal diffusion coefficients computed directly from the measurements for release heights between ground-level and $100 \mathrm{~m}$ and for distances to $10 \mathrm{~km}$ and beyond. Supporting meteorological data in the data base consist of wind and temperature profiles and, in many cases, turbulence measurements.

Development of parameterizations of horizontal diffusion coefficients for elevated releases is an easier task than the development of parameterizations for vertical diffusion coefficients. The primary reasons for the difference are 1)horizontal diffusion coefficients can be computed directly from the available data and 2) a generally accepted framework for the parameteriation of horizontal diffusion coefficients exists. The framework is shown in (2). Parameterization of vertical diffusion coefficients for elevated releases requires selection of a framework from among several alternatives and extensive manipulation of the data to account for differences in experimental conditions.

A new paraineterization of horizontal diffusion rates specifically for elevated releases is not 1 ikely to result in diffusion coefficients that are significantly different, on the average, from horizontal diffusion coefficients that are currently being estimated using parameterizations based on groundlevel release data.

A new parameterization of vertical diffusion rates specifically for elevated releases may give diffusion coefficients that are larger than the coefficients now being estimated on the basis of parameterizations developed from ground-level release data. The differences between diffusion coefficients estimated with a new parameterization and current estimates are likely to be a function of atmospheric stability. Comparison of the elevated release diffusion coefficient curves with the NRC ground-level release curves indicates that the differences should be small for unstable atmospheric conditions and may approach or exceed a factor of three for stable conditions. An increase in vertical diffusion coefficient estimates of this magnitude during stable atmospheric conditions could significantlty affect ground-level concentrations of material released from isolated stacks at nuclear power plants. It would 
result in ground-level time-integrated concentration maxima occuring closer to the plant than with current vertical diffusion coefficient estimates, and the concentration maxima would be larger.

\section{RECOMMENDATIONS}

The development of an elevated release parameterization for vertical diffusion coefficients should receive higher priority than the development of an elevated release parameterization for horizontal diffusion coefficients. The higher priority for the vertical diffusion coefficient parameterization is justified by three considerations: 1) the changes in diffusion coefficient estimates likely to occur with a new parameterization are larger for vertical coefficients than horizontal coefficients, 2) vertical diffusion coefficients affect both the position and magnitude of peak concentrations resulting from elevated releases, and 3) vertical diffusion coefficients are needed in the evaluation of the consequences of both long-term and short-term, accidental releases.

When a parameterization is developed for vertical diffusion coefficients for elevated releases, the parameterization should be based on turbulence measurments (e.g. o o ) or a quantity that is fundamentaliy related to turbulence (e.g. the ratfo between the release height and the Monin-0bukhov length, or the Richardson number). Precedents exist for the use of turbulence measurements in estimating vertical diffusion coefficients (e.g. Islitzer 1961 and Singer and Smith 1966). In addition, Doran, Horst and Nickola (1978) have shown that vertical diffusion coefficients can be predicted successfuliy using similarity theory and the lonin-0bukhov length. The current data base is sufficient to make an attempt to develop a parameterization for elevated release vertical diffusion coefficients worthwhile.

At the time an elevated release parameterization is developed for vertical diffusion rates, consideration should be given to developing a corresponding parameterization for horizontal diffusion rates. The primary reason for upgrading the horizontal diffusion coefficient parameterization is to reduce the uncertainty in coefficient estimates used in evaluation of the consequences of accidental releases. The new parameterization should follow from (2). An American Meteorological Society workshop (Hanna et al. 1977) has recommended this approach; and Doran, Horst and Nickola (1978) and Irwin (1983) have shown that the approach reduces the scatter of diffusion coefficient estimates compared to approaches that require selection of a stability or diffusion classes as an intermediate step in estimating diffusion coefficients.

The use of stability or diffusion classes in estimating diffusion coefficients should be avoided. Their use should be limited to summarization of data for climatological purposes; current on-line data processing techniques make it possible to compute and store quantities that are fundamentally related to diffusion for use in evaluating diffusion coefficients for assessing the consequences of accidental releases. Reduction of the uncertainty in diffusion coefficient estimates provides sufficient reason to avoid the unnecessary use of these classes. In addition to the work of Doran, Horst and Nickola, which 
shows the added uncertainty caused by stability classes, numerous studies have demonstrated the general inconsistencies between various methods of selecting stability classes on an hour-by-hour basis. Among these studies are: Luna and Church (1972). Skaggs and Robinson (1976). DeMarrais (1978), Lalas, Catsoulis and Petrakis (1979), Sedefian and Bennett (1979), and Mitcheli (1982).

Kretzscmar and Mertens (1980) have shown that the inconsistencies that exist on an hour-by-hour basis are masked by the averaging process. Thus, the use of stability classes may be acceptable for evaluation of routine releases, even though they are undesirable in the evaluation of accidental releases. 


\section{REFERENCES}

Bacci, P., G. Elisei and A. Longhetto. 1974. "LIDAR Measurement of Plume Rise and Dispersion at 0stiglia Power Station," Atmos. Environ., 8:1177-1186.

Bander, T. J. 1982. PAVAN: An Atmospheric Dispersion Program for Evaluating Design Basis Accidental Releases of Radioactive Materials from Nuclear Power Stations. NUREG/CR-2858 (PNL-4413), U.S. Nuclear Regulatory Commission, Washington, D. C.

Barad, M. L. and B. Shorr. 1954. "Field Studies of the Diffusion of Aerosols," Am. Ind. Hygene Assoc. Quart. 15:.

Erown, R. M., L. A. Cohen and M. E. Smith. 1972. "Diffusion Measurements in the 10-100 km Range," J. Appl. Meteor., 11:323-334.

Chaudhry, F. H. and R. N. Meroney. 1973. "Similarity Theory of Diffusion and the Observed Vertical Spread in the Diabatic Surface Layer," Bound.-Layer Meteor., 3:405-415.

DeMarrais, G. A. 1978. "Atmospheric Stability Class Determinations on a 481Meter Tower in 0klahoma," Atmos. Environ., 12:1957-1964.

Doran, J. C., T. W. Horst and P. W. Nickola. 1978. "Experimental Observations of the Dependence of Lateral and Vertical Dispersion Characteristics on Source Height," Atmos. Environ., 12:2259-2263.

Elderkin, C. E., D.C. Powell and P.W. Nickola. 1974. "Diffusion-Deposition Measurements and Modeling," Symposium on Atmospheric Diffusion and Air Pollution of the American Meteorological Society, Santa Barbara, cA.

Eimutis, E. C. and M. G. Konicek. 1972. "Derivations of Continuous Functions for the Lateral and Vertical Atmospheric Dispersion Coefficients," Atmos. Environ., 6:859-863.

Gifford, F.A. 1961. "Use of Routine Meteorological Observatons for Estimating Atmospheric Dispersion," Nucl. Safety, 2:47-51.

Gifford, F. A. 1980. "Smoke as a Quantitative Atmospheric Tracer," Atmos. Environ., $14: 923-931$.

Gryning, S-E. and E. Lyck. 1980. "Medium-Range Dispersion Experiments Downwind from a Shoreline in Near Neutral Conditions," Atmos. Environ., $14: 923-931$.

Gryning, S-E. and E. Lyck. 1981. "Results from Elevated-Source Urban Area Dispersion Experiments Compared to Model Calculations," 12th International Tech. Meeting on Air Pollution Modeling and Its Applications, CCMS/NATO, PenTo Park, CA. 
Hanna, S. R., G. A. Briggs, J. Deardorff, B. A. Egan, F. A. Gifford and F. Pasquill. 1977. "AMS Workshop on Stability Classification Schemes and Sigma Curves -- Summary of Recommendations," Bu11. Am. Meteorol. Soc., 58:13051309.

Hanna, S. R. 1980. "Measured $\sigma_{y}$ and $\sigma_{\theta}$ in Complex Terrain Near the TVA Widows Creek, Alabama Steam Plant," Atmos. Environ., 14:401-407.

Hay, J. S., and F. Pasquill. 1957. "Diffusion From a Fixed Source at a Height of a Few Hundred Feet in the Atmosphere," J. Fluid Mech., 2(part 3):299-310.

Hilst, G. R. 1957. "The Dispersion of Stack Gases in Stable Atmospheres", 50th leeting of the Air Pollution Control Association.

Hi 1st, G. R. and C. L. Simpson. 1958. "Observations of Vertical Diffusion Rates in Stable Atmospheres." J. Meteorol., 15:125-126.

Hoff, R. M. and F. A. Froude. 1979. "LIDAR Observation of Plume Dispersion in Northern Alberta," Atmos. Environ., 13:35-43.

Hoff, R. M., F. A. Froude, N. B. A. Trivett, M. M. Millan, P. Fellin, K. G. Ahlauf and H. A. Wiebe. 1982. "The Nanticoke Shoreline Diffusion Experiment, June 1978 -- III. Ground-Based Air Quality Measurements," Atmos. Enviran., $16: 439-454$.

Irwin, J. S. 1983. "Estimating Plume Di spersion -- a Comparison of Several Sigma Schemes," J. Climate and Appl. Meteor., 22:92-114.

Islitzer, N. F. 1961. "Short-Range Atmospheric Dispersion Measurements from an Elevated Source," J. Meteorol., 18:443-450.

Is litzer, N. F. and 0. H. Slade. 1968. "Diffusion and Transport Experiments," in Meteorology and Atomic Energy - 1968. TID-24190, U.S. Atomic Energy Cominission, Washington, DC.

Johnson, W. B. 1969. "LIDAR Observations of the Diffusion and Rise of Stack Pl umes," J. Appl. Meteor., 8:443-449.

Johnson, W. B. and E. E. Uthe. 1971. "LIDAR Study of the Keystone Stack Plume," Atmos. Environ., 5:703-724.

Kretzschmar, J. G. and I. Mertens. 1980. "Influence of Turbulence Typing Schemes Upon the Yearly Average Ground-Level Concentrations Calculated by Means of a Mean Wind Di rection Model," Atmos. Environ., 14:947-951.

Lalas, D. P., V. Catsoulis, and M. Petrakis. 1979. "On the Consistency of Stability Classification Schemes when Applied to Non-Homogeneous Terrain," Atmos. Environ., 13:687-691. 
Luna, R. E. and H. W. Church. 1972. "A Comparison of Turbulence Intensity and Stability Ratio Measurements to Pasquill Stability Classes," J. Appl. Meteor., 11:663-669.

Mitchell, A. E., Jr. 1982. "A Comparison of Short-Term Dispersion Estimates Resulting from Various Atmospheric Stability Classification Methods," Atmos. Environ., 16:765-773.

Moore, D. J. 1974. "The Prediction of the Mean Hourly Average Maximum Ground Levei Concentration of Sulphur Dioxide at Tilbury," Atmos. Environ., 8:543554.

Nickola, P. W. 1977. The Hanford 67-Series: A Volume of Atmospheric Field Diffusion Measurements. PNL-2433, Pacific Northwest Laboratories, Richland, WA.

Nickola, P. W. 1979. "Field Measurements of the Benefits of Increased Stack Height," U. Appl. Meteor., 18:1296-1303.

Pasquill, F. 1961. "The Estimation of the Dispersion of Windborne Material," Meteorol. Mag., 90:33-49.

Peterson, K. R. 1968. "Continous Point Source Plume Behavior Out to 160 Miles," J. Appl. Meteor., 7:217-226.

Powell, D. C., H. L. Wegley and T. D. Fox. 1979. MESODIF-II: A Variable Trajectory Plume Segment Model to Assess Ground-Level Air Concentrations and Deposition of Effluent Releases from Nuclear Power Facilities. NUREg/CR-0523 (PNL-2419), U. S. Nuclear Regulatory Commission, Washington, D.C.

Sagendorf, J. F., J. T. Goll and W. F. Sandusky. 1982. X00D0Q: Computer Program for the Meteorological Evaluation of Routine Effluent Releases at Nuclear Power Stations. NUREG/CR-2919 (PNL-4380), U. S. Nuclear Regulatory Commission, washington, D.C.

Sedefian, L. and E. Bennett. 1980. "A Comparison of Turbulence Classification Schemes," Atmos. Environ., 14:741-750.

Singer, 1. A. and M. E. Smith. 1966. "Atmospheric Dispersion at Brookhaven National Laborotory," Int. J. Air and Wat. Pollut., 10:125-135.

Skaggs, D. L. and E. Robinson. 1976. "A Comparison of Methods for Estimating Atmospheric Stability and Diffusion Coefficients," J. Air Pollut. Control AsSOC., 26:888-891.

Smith, M. E. 1956. "The Variation of Effluent Concentrations from an Elevated Point Source," A. M. A. Archives of Ind. Health, $14: 56-68$.

Start, G. E., C.R. Dickson and L. L. Wendell. 1975. "Diffusion in a Canyon Within Rough Mountainous Terrain," $\mathrm{J}$. Appl. Meteor., 14:333-346. 
Stewart, N. G., H. J. Gale and R. N. Crooks. 1958. "The Atmospheric Diffusion of Gasses Discharged from the Chimney of the Harwell Reactor, BEPO," Intern. J. Air Pollut., $1: 87-102$.

Stewart, R. E. 1968a. "Atmospheric Diffusion of Particulate Matter Released from an Elevated Continuous Source," J. Appl. Keteor., 7:425-432.

Stewart, R. E. 1968t). "Estimating Lateral Growth Rate of a Particulate Plume," J. Appl. Meteor., 7:947-950.

Thomas, P., W. Hubschmann, L. A. Konig, H. Schuttelkopf, S. Bogt and A. Winter. 1976. Experimental Determination of the Atmospheric 0ispersion Parameters Over Rough Terrain-Part 1: Measurements at the Karlsruhe Nuclear Research Center. KFK 2285.

Thomas, P. and K. Nester. 1976. Experimental Determination of the Atmospheric Dispersion Parame ters Over Rough Terrain-Part 2: Evaluation of Measurements. KFK 2286.

U.S. Nuclear Regulatory Commission. 1974. Onsite Meteorological Programs. Regulatory Guide 1.23 (formerly Safety Guide 23), Washington D.C.

Uthe, E. E. and W. B. Johnson. 1976. LIDAR Observations of Plume Diffusion at Rancho Seco Generating Station. Final Report EPRI NP-238, Electric Power Research Institute, Palo Alto, CA.

Uthe, E. E. and W. E. Wilson. 1979. "LIDAR Observations of the Density and Behavior of the Labadie Power Plant Plume," Atmos. Environ., 13:1395-1412.

Uthe, E. E., F. L. Ludwig and F. Pooler, Jr. 1980. "LIDAR Observations of the Diurnal Behavior of the Cumberland Power Plant Plume," J. Air Pollut. Cont. AsSOC., 30:889-893.

Voyt, K. J. and H. Geiss. 1974. Tracer Experiments on the Dispersion of Plumes Over Terrain of Major Surface Roughness. Berichte der Kernforschuncysanlage JuTich - Nr. 1131. Julich, Federal Republic of Germany.

Whaley, H. 1974. "The Derivation of Plume Dispersion Parameters from Measured Three-Dimensional Data." Atmos. Environ., 8:281-290.

Whaley, H. and G. K. Lee. 1977. "Plume Dispersion in a Mountainous River valley During Spring," J. Air Pollut. Cont. Assoc., 27:1001-1005.

Whaley, H. and G. K. Lee. 1978. "An Assessment of Plume Dispersion Paraneters Measured in Fall and Winter at a Tar-Sands Refinery Complex," A. Air Pollut. Cont. Assoc., 28:589-593.

Whaley, H., G. K. Lee and J. G. Gainer. 1980. "The Behavior of Buoyant Merging Plumes in The Rocky Mountain Foothills," J. Air Pollut. Cont. Assoc., 30:782-786. 


\section{DISTRIBUTION}

No. of

Copies

OFFSITE

U.S. Nuclear Regulatory Commission

Division of Technical

Information and Document

Control

$4 \mathrm{Mr}$. J. Fairobent

Division of System Integration

Office of Nuclear Reactor Regulation

U.S. Nuclear Regulatory

Commission

Washington, DC 20555
No. of

Copies

ONSITE

50 Pacific Northwest Laboratory

K. J. Altwine

G. F. Athey

D. W. Dragnich

J. C. Doran

J. G. Droppo

D. W. Faletti

C. S. Glantz

R. K. Madlock

C. G. Lindsey

M. A. McLean

J. V. Ramsdell (31)

W. F. Sandusky

C. D. Whiteman

Publishing Coordination (2)

Technical Information (5) 


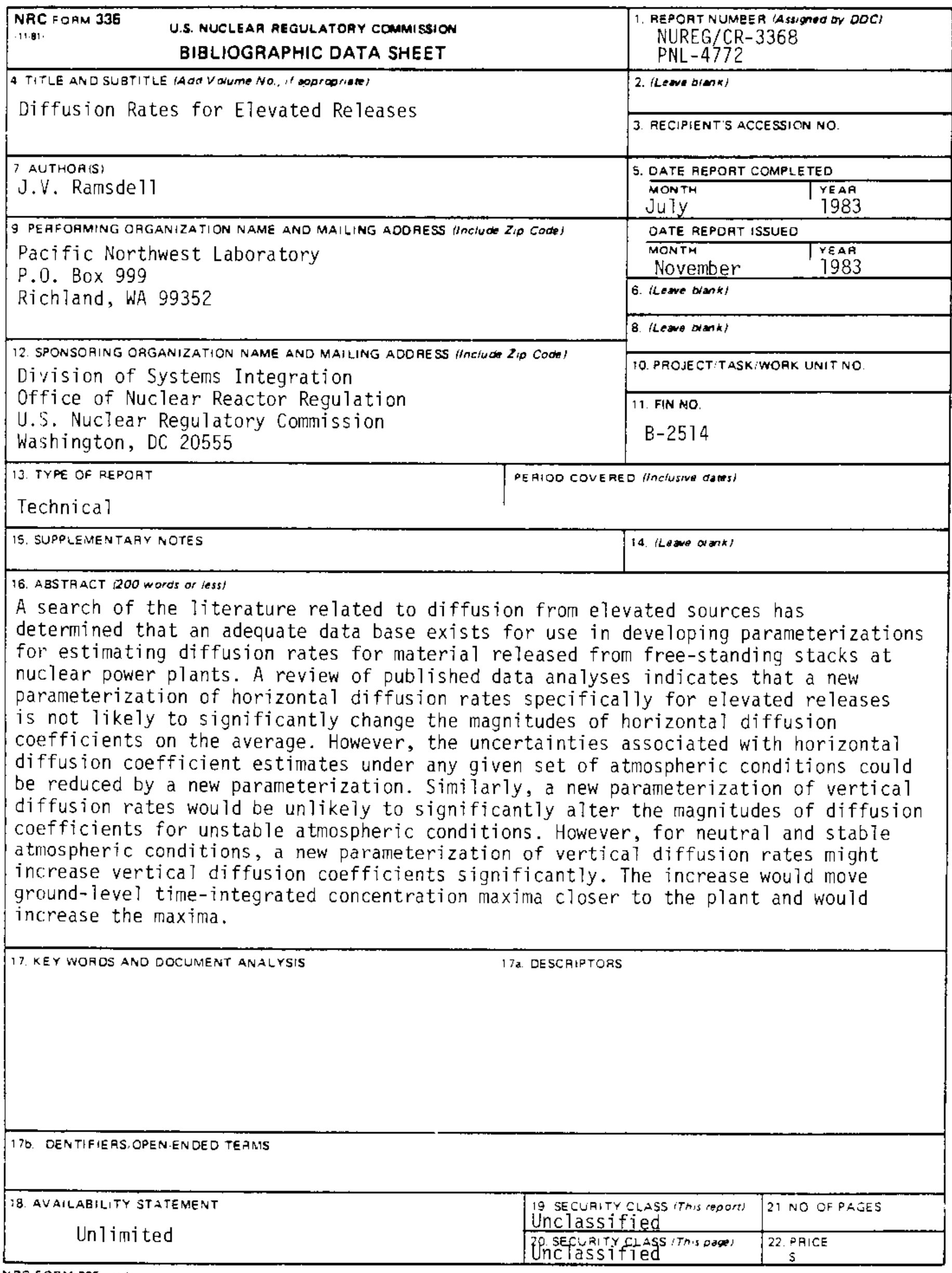


